\title{
Srovnávací výzkum v pedagogice: některé úvahy o metodologii problémového prrístupu
}

\author{
Petr Vlček \\ Masarykova univerzita, Pedagogická fakulta, Katedra tělesné výchovy \\ Redakci zasláno 25. 9. 2013 / upravená verze obdržena 3. 4. 2015 / \\ k uveřejnění přijato 28. 4. 2015
}

\begin{abstract}
Abstrakt: Studie se zaměřuje na vybrané problémy metodologie srovnávacího výzkumu v pedagogice s cílem přispět do debaty o metodologické kvalitě komparativního výzkumu. Snahou autora je pokusit se provést čtenáře procesem vědeckého srovnávání v pedagogice založeném na problémovém přístupu. Vedle stručných teoretických a historických východisek studie, které tvoř́ základnu pro autorovy další úvahy, jsou v textu uvedeny některé principy pedagogické komparatistiky. Ty autor opírá o současné pojetí srovnávací pedagogiky, její výzkumné pole a vybrané druhy komparativního výzkumu. Následně jsou stručně představeny jednotlivé kroky komparativní vědecké metody. Závěrečné odstavce jsou věnovány úvahám o roli deskriptivních a př́padově orientovaných studií v komparativním pedagogickém výzkumu, a to zejména z pohledu metodologie problémově orientovaného př́stupu.
\end{abstract}

Klíčová slova: srovnávací pedagogika, metodologie, problémový přístup

Srovnávání je obecný poznávací prostředek, je to základní myšlenková operace, kterou používáme prakticky neustále. Ve vědě se srovnávání neboli komparace užívá také ve smyslu výzkumné metody, na jejímž základě se konstituují specifické výzkumné specializace, či dokonce samostatné disciplíny, jejichž základní metodologie spočívá právě ve srovnávání. Komparace ve smyslu vědecké metody je využívána $v$ rámci studia psychologie, ekonomiky, politiky, náboženství atd. Zřetelně se komparativní výzkum konstituoval jako relativně svébytný obor v jazykovědě (srovnávací jazykověda), obdobně existuje srovnávací literární věda (literární komparatistika). Zvláštní význam a tisíciletou historii má srovnávací metoda ve vědě právní, kde je označována jako právní komparatistika. ${ }^{1}$ Také v pedagogice se $\mathrm{v}$ mnoha

1 Srovnávací pedagogika je často s těmito vědami porovnávána. Tak je vymezován její obsah, rozsah i relativní samostatnost mezi vědními disciplínami (Corbineau-Hoffmann, 2004; Váňová, 1998). Také metody používané ve srovnávací pedagogice jsou často přejímány z jiných oborů (Bereday, 1957, s. 13). 
zemích konstituoval více či méně nezávislý obor (Manzon, 2011 aj.) v českém prostředí označovaný jako srovnávací pedagogika, jenž používá komparaci jako vědeckou metodu. Srovnávací pedagogika jako oblast systematického bádání má více než stoletou historii. ${ }^{2}$ Za tuto dobu prošla různými vývojovými fázemi, ve kterých se prosazovaly rozdílné motivy, funkce a paradigmata, ovlivňující také přístupy a metody používané ve srovnávacím pedagogickém výzkumu. Také proto, že naše poznání se $\mathrm{v}$ dané oblasti neustále vyvíjí, je diskuse týkající se metodologických pravidel komparativního výzkumu jedním ze stále aktuálních témat (nejen české) srovnávací pedagogiky (Bray \& Thomas, 1995; Manzon, 2011; Noah \& Eckstein, 1969). Cílem předložené studie je proto přispět do debaty týkající se metateorie srovnávací pedagogiky s primárním zaměřením na problematiku metodologie srovnávacího výzkumu v pedagogice.

Jedním z českých i zahraničních specifik (Manzon, 2011; Walterová, 2014) je, že metodologický diskurs není rozvíjen systematicky a i přes svou rozsáhlou poznatkovou základnu vykazují texty některých autorů určité z pohledu moderní pedagogické komparatistiky problémové rysy. Rukopisy bývají z velké části deskriptivní, mají často narativní charakter, postrádají explanace, hledání a navrhování řešení. Různá míra autorské zkušenosti často způsobuje například to, že svým rozsahem objemné studie prezentují v časopisech a zejména na konferencích málo podložené a ověřené výsledky srovnávacího výzkumu. Někteří autoři se v kapitole o použité metodologii více či méně omezí na informaci, že jako metoda vědeckého zkoumání byla použita metoda srovnávání.

Jak již bylo řečeno, ve studii se budeme primárně soustředit na metodologii srovnávacího výzkumu v pedagogice. I přes naši snahu nahlížet na tuto problematiku komplexně, rozsahové limity časopisecké studie ji neumožňují obsáhnout celkově a encyklopedicky. Navíc dříve než se v předložené studii propracujeme k vlastní metodě komparativního výzkumu, považujeme za nutné alespoň stručně pojednat o některých teoretických a historických souvislostech, například o různých pohledech a možnostech členění srovnávacího výzkumu, zejména dle teritoriálního členění. Následovat bude krátký exkurz do historického vývoje srovnávací pedagogiky a stručné pojednání o výzkumném poli a některých principech srovnávacího výzkumu $\mathrm{v}$ pedagogice.

2 Problematikou srovnávací pedagogiky a procesy její institucionalizace jako vědního oboru se zabývali např. Noah a Eckstein (1969), Manzon (2011) aj. 


\section{Různé pohledy na členění srovnávacích výzkumů v pedagogice}

Různost porovnávaného jevu lze hledat zejména $\mathrm{v}$ prostoru a $\mathrm{v}$ čase. Pedagogičtí komparatisté se proto shodují, že srovnávání může být v zásadě dvojí povahy. Diachronní (vertikální) srovnávání následných pedagogických jevů a synchronní (horizontální) srovnávání jevů vyskytujících se v téže době v různých státech ${ }^{3}$ (Jůva, 1994; Mahoney \& Rueschemeyer, 2003; Walterová, 2006). Pro oba druhy komparace platí stejný požadavek, totiž že prostor i čas je třeba co nejpřesněji vymezit.

Diachronní neboli chronologický způsob komparace, pro který je zásadní tok času, spočívá ve srovnávání současných pedagogických jevů s jeho dřívějšími ekvivalenty, např́íklad Jirečkova studie (2010). Tento způsob komparace lze označit také jako komparatistiku historickou (Mahoney \& Rueschemeyer, 2003).

Při synchronním srovnávání hraje roli vymezení různě definovatelného prostoru. Hovoří se například o mezinárodním srovnávání, regionální komparatistice, interkulturním výzkumu atd., ale také o srovnávání škol, tříd nebo jednotlivců (Bray \& Thomas, 1995). Zvolení prostorových charakteristik podstatných pro daný výzkumný problém nelze teoreticky předurčit. Jejich výběr je v podstatě fakultativní s ohledem na výzkumný problém a výzkumné otázky. Podstatné je, aby se výzkumník soustředil na konkrétní případ a vybral a správně terminologicky uchopil stěžejní determinanty (Noah \& Eckstein, 1969, s. 91). ${ }^{4} \mathrm{~V}$ př́ípadě že autor označuje svůj výzkum za interkulturní, měl by se pokusit vypořádat s pojmem kultura (Zerzová, 2012 aj.), pokud se například hovoří o regionálním srovnávání, je třeba vymezit konkrétní regiony. Shrňme, že v této oblasti je třeba dodržet systémový a vědecký postup. Poznamenejme také, že např́íklad definice srovnávací pedagogiky jako „vědní disciplíny zabývající se srovnáváním vzdělávacích systémů nebo jejich částí ve dvou nebo více zemích" (Průcha, Walterová, \& Mareš, 2003, s. 226) operuje s pojmem země. Z hlediska našeho výkladu o exaktním vymezení

Ovšem nemusí se jednat pouze o státy, viz další odstavce.

Může se např́íklad stát, že namísto prostorového vymezení se komparativní studie zaměří na srovnání určitého ohraničeného systému, například školského. Potom lze hovořit o systémové komparatistice, která může být blíže specifikována (to když jsou analyzovány jen jednotlivé elementy nebo aspekty, Seebauer, 2003, s. 115) např́klad jako komparatistika mezioborová (např. Píšová et al., 2011). Další možná členění srovnávacích studií z hlediska prostoru a času uvádí Bray, Adamson a Mason (2007) v obsáhlé kapitole Units of comparison. 
prostoru by v uvedené definici bylo přesnější použít pojem stát (Walterová, 2006, s. 34, 96) a opř́ít se o teorii státovědy, např́íklad Jellinekovu (1882) tř́íprvkovou definici vymezující stát jeho územím, státním obyvatelstvem a státní mocí. ${ }^{5} \mathrm{Z}$ právní komparatistiky lze převzít pojmy makrokomparace a mikrokomparace. V př́padě makrokomparace se jedná o mezistátní srovnávání. ${ }^{6}$ Pojmem mikrokomparace lze označit srovnání menších souborů, např. vybraného oboru školního kurikula, konkrétních škol nebo např́íklad žáků či pedagogických pracovníků (Bray \& Thomas, 1995). Podle teritoriálního principu můžeme tedy komparativní výzkum rozdělit na několik typů - srovnávání národní, regionální nebo lokální (Seebauer, 2003, s. 115). Předchozí výklad shrňme tím, že někteří autoři (Bray \& Thomas, 1995, s. 484; Elley, 1994; Keeves \& Sellin, 1988, s. 690; Knapp, 1991, s. 20; Papanastasiou \& Froese, 2002) upozorňují, že tzv. multilevel studie ${ }^{7}$ mohou přinést kompletnější a vybalancovanější porozumění dané problematice. Sami autoři však konstatují skutečnost, že vypracování takovýchto studií vyžaduje týmovou spolupráci a je i v jiných pohledech velice náročné. Noah a Eckstein (1969) v této souvislosti hovoří o ekonomice výzkumu, tedy o tom, že např́íklad jen některá data jsou pro daný výzkumný problém relevantní (jiná méně nebo vůbec), a zdůrazňují, že jejich výběr plyne z konkrétního výzkumného problému (viz další text).

\section{Stručný exkurz do historického vývoje srovnávací pedagogiky}

Ačkoli rozsahová omezení předložené studie neumožňují pojednat historický vývoj srovnávací pedagogiky celkově, ${ }^{8}$ pro logiku úvah uvedených v dalším textu považujeme za nutné se této problematice ve stručnosti věnovat. Historický vývoj srovnávací pedagogiky se dělí do několika etap, pro které jsou charakteristické odlišné motivy komparativního výzkumu a produkce

5 V teorii státovědy existují také další teorie a způsoby, jak vymezit pojem stát. K tomu blíže např́iklad Filip, Svatoň a Zimek (2004).

6 Na tomto místě je třeba upozornit také na problém federalismu nebo obecněji řečeno různých forem státního zřízení (Bray \& Thomas, 1995, s. 478-480).

7 Bray a Thomas (1995) uvádí sedm úrovní, ve kterých se provádí komparativní výzkum $\mathrm{v}$ pedagogice. $\mathrm{V}$ originálním jazyce autoři dělí úrovně na: continent, country, state, district, school, classrooms, individuals. Z hlediska státovědecké teorie by český překlad mohl být: kontinenty, federace a unie, státy a provincie, správní celky, školy, tř́dy, jednotlivci.

8 Zde odkazujeme na monografie (např. Cowen, 2009; Manzon, 2010; Váňová, 1998; Walterová, 2006, ze starší literatury Noah \& Eckstein, 1969, apod.). 
žánrově odlišných prací. Komparatisté (Halls, 1990; Noah \& Eckstein, 1969; Průcha, 2006; Váňová, 1998; Walterová, 2006 aj.) se více méně shodují na členění do čtyř nebo pěti etap. Jako první je uváděna etapa cestovatelů, ve které motivem byla prostá zvědavost. Druhá je etapa výzkumníků, kteří sbírali údaje, aby na základě zkušeností z ciziny zlepšili svůj národní školský systém. Poté následovala etapa mezinárodní spolupráce. Ve dvacátém století lze identifikovat etapu klasickou, kde výzkumným motivem a funkcí srovnávací pedagogiky bylo hledání sil a faktorů, které tvoří národní vzdělávací systémy, a etapu sociálněvědní explanace objasňující vztahy a vzájemné vlivy mezi vzděláváním a společností. I když se v obou těchto etapách postupně prosazovala snaha badatelů o vysvětlování a objasňování vzájemné interakce mezi společností a vzděláváním, v klasické etapě se jedná spíše o jejich intuitivní počínání. Až v poslední fázi se např. podle Beredaye (1966), Noaha a Ecksteina $(1969$, s. 82) objevují nové metodologické požadavky na komparativní studie, podle nichž nelze považovat žádné explanace sociálně vzdělávacích jevů za validní, pokud jim nepředcházel precizně provedený výzkumný proces. Ačkoli jsou diskuse o funkci srovnávací pedagogiky, širri jejího výzkumného pole i samotné definici oboru stálým tématem (Manzon, 2011), v současnosti je srovnávací pedagogika chápána jako

interdisciplinární podobor pedagogiky (studií o vzdělávání), který systematicky zkoumá podobnosti a rozdíly mezi vzdělávacími systémy ve dvou nebo více národních či kulturních kontextech a jejich interakce s vnitřním a vnějším kontextem vzdělávání. Specifickým objektem jsou vzdělávací systémy zkoumané průřezově v kulturní (národní, regionální) perspektivě prostřednictvím systematického užívání komparativní metody, za účelem dosažení teoretického porozumění a budování teorie. (Manzon, 2011, s. 215)

\subsection{K metodologickým principům komparatistiky v pedagogice}

V následujících odstavcích se pokusíme uvést a diskutovat některé principy, které mohou pomoci určit př́íslušnost vědeckých studií k oborovému spektru srovnávací pedagogiky. ${ }^{9}$

Aby dle současných trendů srovnávací pedagogiky bylo možné provádět explanace pedagogických jevů na základě komparace ve smyslu vědecké metody, srovnávaných jevů musí být více, musí být srovnatelné a musí jít

9 Jiné členění metodologických principů ve srovnávací pedagogice uvádí Průcha (2006, s. 38-39). 
o systematické vysvětlování poznatků a hledání kauzalit v celkovém kontextu mající vědecký charakter. $\mathrm{Z}$ uvedeného lze dovodit několik metodologických principů komparatistiky v pedagogice, kterými jsou pluralita, srovnatelnost, kontextualita a vědeckost.

\section{Pluralita}

Hilker (1962, s. 100; také Váňová, 1998 aj.) uvádí, že mezi dvěma nebo více jevy stejného druhu se vytváří vztah založený na shodě (kongruenci), podobnosti (afinitě) nebo rozdílnosti (diskrepanci). V př́padě podobnosti se shodují některé určující znaky. Rozdílné jevy se shodují málo nebo vůbec. Mluvíme-li o shodě, jde bud' o identický jev, nebo jsou komparované jevy shodné vzhledem ke stanovenému problému do té míry, že jejich komparace nepřináší nic nového. Aby se z komparace zrodily nové poznatky, je důležité hledat především podobné a také rozdílné jevy, pokud jejich rozdílnost není př́liš velká. Aby se tedy jednalo o bezvýhradně komparativní výzkum, musí být srovnávány minimálně dva konkrétní, skutečné a určitým způsobem postižitelné jevy (Bereday, 1957, 1966; Manzon, 2011; Štefanovič, 1996; Váňová, 1998).

\section{Srovnatelnost}

Dalším principem vědecké komparace je srovnatelnost. Znamená to, že srovnávané aspekty nesmí být zcela heterogenní, nýbrž musí vedle odlišností existovat i podobnosti srovnávaných jevů či objektů (Váňová, 1998, s. 59). Podle Walterové (2006, s. 21; Noah \& Eckstein, 1969, s. 94) proto komparace vyžaduje přesné vymezení objektů (jevů) srovnávání, tj. kdo nebo co je srovnáváno s kým nebo čím a které vlastnosti nebo znaky obou jevů jsou srovnávány. Pro použití srovnávací metody pak platí elementární požadavek, aby comparatum a comparandum, jak jsou v komparatistice označovány srovnávané jevy, bylo překlenuto nějakým tertiem comparationis, neboli společným pojmem vyšší obecnosti. Ten Váňová (1998, s. 59) charakterizuje jako v individuální nebo obecné rovině stanovenou hodnotu, umožňující posouzení př́íslušnosti či nepříslušnosti charakteristik dvou nebo více objektů ke společnému kritériu. Knapp (1991, s. 16) v této souvislosti upozorňuje na filozofickou otázku obecných pojmů. ${ }^{10}$ Základní a nezbytný požadavek komparace je tedy možnost $\mathrm{z}$ obou srovnávaných jevů, které jsou odborně

10 Podle Knappa (1991) je otázkou, do jaké míry (do jakého stupně obecnosti) má smysl abstrahovat, aby srovnávání ještě mohlo přinést nějaký vědecký poznatek. 
pojmenovány, abstrahovat společný pojem vyšší, jenž je ve vztahu ke comparatu a comparandu pojmem obecnějším. Je to pojem, do jehož rozsahu náleží jak comparatum, tak comparandum.

Zásadní roli zde hraje také úhel pohledu na zkoumaný jev, tedy paradigmatické východisko (Holmes, 1984). V komparatistice je možné rozlišit dva různé úhly pohledu. Pohled relativistický a univerzalistický. Relativizmus vychází z předpokladu neopakovatelnosti určitého jevu v čase i prostředí. Z tohoto důvodu je pak každý jev posuzován pouze v jeho vlastním kontextu, např́iklad v souvislostech s hodnotami, idejemi, normami a tradicemi určité kultury (Brandl-Bredenbeck, 2005, s. 27). Podle Váňové (1998) relativisté provádějí idiografické výzkumy, jejichž cílem je zjistit speciální okolnosti, které od sebe odlišují jednotlivé případy. Zdůrazňují tak rozdíly a odmítají existenci zákonotvorných principů.

Zcela odlišný pohled na otázku srovnatelnosti a cíl komparace má universalismus. Tento filosofický směr zdůrazňuje srovnatelnost studovaných faktů a komparaci bere jako prostředek k odhalování obecných vzorců a vyvozování obecných principů a zákonitostí (Brandl-Bredenbeck, 2005, s. 27; Váňová, 1998, s. 61). Myslitelé představující tento směr tvrdí, že lidské chápání světa je v podstatě stejné, nebot' vždy existují tzv. universálie neboli obecně platné znaky (Boehne \& Merkens, 1994, s. 214).

V textech dalších autorů (Adamson \& Mason, 2007; Brandl-Bredenbeck, 2005; Bray, 1990; Hendl, 2005; Michael, 1999; Richter, 2006; Vlček \& Janík, 2010) je výše popsané dvojí paradigma označováno také jako emické a etické. Pohled etický je pohled z perspektivy pozorovatele a objektivizující vědy, hledá to společné a nebere ohled na odlišnosti. Pohled emický vychází z relativismu a je tudíž závislý na kontextu, kategoriích a představách aktérů jednání neboli na axiomatickém pohledu člena zkoumané skupiny.

Shrňme tedy, že z pohledu námi diskutovaných principů komparatistiky $\mathrm{v}$ principu srovnatelnosti dominuje universalistický (etický) pohled, který hraje zásadní roli pro nalezení tertia comparationis. Prizma emické na druhou stranu hraje zásadní roli v dalším principu komparatistiky, $\mathrm{v}$ principu kontextuality. 


\section{Kontextualita ${ }^{11}$}

Z výše uvedeného je patrné, že princip kontextuality do značné míry souvisí s principem srovnatelnosti. Jde především o to, že vědecké poznání obecně je pronikání od jevu k podstatě, a proto i komparatistický výzkum vyžaduje poznání podstaty srovnávaných jevů (Knapp, 1991; Liu, 2008; Noah \& Eckstein, 1969, s. 97). Tento postup není nezbytný pouze ve vlastním komparatistickém poznávacím procesu, ale také pro vědecké stanovení obecného pojmu, který v dané komparaci slouží jako tertium comparationis. Ne vždy je jednoduché najít adekvátní comparatum a comparandum. Můžeme nalézt zdánlivě velice podobný objekt (jev), např. ve školských systémech dvou států, ale při bližším srovnávání zjistíme, že kupř́íkladu jeho obsah, uplatnění či společensko-praktický dosah je zcela odlišný. Srovnávali bychom prakticky nesrovnatelné (viz funkční, strukturální a lingvistická ekvivalence - Liu, 2008, s. 27; Průcha, 2006, s. 38-39, 49-52). Na příkladu Váňové (1998, s. 59) lze tyto myšlenky demonstrovat takto: „Srovnatelnost některých univerzitních diplomů v rámci Evropské unie nemusí nutně znamenat, že cesta k jejich získání je identická, ba ani podobná." Shrňme tedy, že kontextualita je podstatným principem komparatistiky, protože pedagogické jevy je třeba srovnávat v celkovém kontextu, a to jak v současné době, tak i z hlediska změn a vývojových tendencí určitého jevu v průběhu času.

V předchozím textu jsme zmínili, že v principu kontextuality hraje zásadní roli emický pohled na zkoumanou skutečnost. Axiomatický pohled člena zkoumané skupiny umožňuje přesně postihnout zásadní kontext zkoumaného problému. Ovšem každý člověk (i komparativní badatel) si v sobě nese jisté vzorce myšlení, cítění a jednání (Zerzová, 2012, s. 20). Hofstede a Hofstede (2005) tyto vzorce přirovnávají k „softwaru mysli“ a vycházejí z předpokladu, že myšlenkové vzorce jsou ovlivňovány specifickými sociálními, geografickými, historickými, náboženskými, politickými aj. faktory. Tedy prostředím, ve kterém jedinec vyrůstal a sbíral své životní zkušenosti. ${ }^{12}$ Pro komparativní výzkum má tento fakt pozitivní význam. Nesporným kladem je, že různé úhly pohledu komparatistů s odlišným „softwarem mysli“ představují v podstatě nekonečné hranice komparativního výzkumu. Komparatistika tak může neustále posouvat své horizonty. Na druhou stranu nevýhodou komparativních

11 Váňová (1998) hovoří o globalitě, Seebauerová (2003) o celostním chápání reality. Noah a Eckstein (1969, s. 40-57) si všímají toho, v jaké době začal být celostní přístup chápán jako důležitý metodologický princip srovnávací pedagogiky.

12 K tomu se blíže vyjadřují také Noah a Eckstein $(1969$, s. 88). 
výzkumných prací, jejichž východiska tvoří různé postuláty, by mohla být jejich obtížná srovnatelnost. Ovšem dle našich úvah není v případě problémově orientovaného př́stupu podstatná srovnatelnost vědeckého postupu, nýbrž srovnatelný výzkumný problém a komparace relevantních výzkumných zjištění vzhledem ke kontextovým faktorům prostřednictvím rigorózního vědeckého postupu.

\section{Vědeckost}

Věda není pouze dosažené poznání, je to i proces, jímž se tohoto poznání dosahuje (Kuhn, 1962; Skalková, 1979 aj.). Autoři hovoří o vědě jako o systému rozvíjejících se poznatků, jež získáváme pomocí příslušných metod neboli pravidel, podle kterých se dobíráme poznání. $V$ úvodu jsme uvedli, že srovnávání je základní myšlenková operace, ale ve vědě je užíváno jako výzkumná metoda. Podle Ochrany $(2009$, s. 12) je vědecká metoda systematickým, promyšleným a objektivním postupem k získání poznatků a dosažení cíle. Je to způsob, jak od určitého východiskového stavu dospět určitou uspořádanou (cílevědomou) činností k nalezení či objasnění vědeckých poznatků a zákonitostí zkoumaného problému (Bereday, 1966, s. 15; Noah \& Eckstein, 1969, s. 91). Pro pedagogickou komparatistiku to znamená, že použití metody při vědeckém zkoumání předpokládá znát postup a umět kompletně použít komparativní vědeckou metodu (Skalková, 1995, s. 21) především za účelem dosažení cíle, kterým je objasnění výzkumného problému.

\section{Komparativní vědecká metoda}

Obecně se o výzkumu v pedagogice vyjadřuje Skalková (1979), upozorňujíc na to, že fakta je třeba shromažd'ovat koncepčně a systematicky. Shromažd'ování faktů nevycházejících z promyšlených teoretických východisek (Noah \& Eckstein, 1969, s. 64) znemožňuje odhalovat objektivní vztahy a dospět k pravdivému poznání skutečnosti. Vědecko-výzkumný proces problémově orientované komparatistiky začíná v mysli výzkumníka velice často obecným vědomím o existenci problému. Rigorózní studium relevantní problematiky je základním předpokladem pro formulaci problému. Poznatky pro objasnění a řešení problému se pak získávají systematickým postupem neboli výzkumnou metodou. Metoda by měla být spolehlivá tak, aby jiný badatel, zkoumající stejné penzum informací, dosáhl přibližně stejných závěrů. Volba konkrétního postupu vedoucího k vyřešení problému záleží zejména na jeho povaze, ale také např́iklad na druhu a dostupnosti dat. 
V následujícím textu uvedeme klasický komparatistický postup, který navrhl ve své stěžejní knize G. Bereday (1966). Beredayem navržený problémový přístup ke komparatistice, jehož počáteční a stěžejní fází je formulace problému (Bereday, 1966, s. 23; Holmes, 1965; Manzon, 2007; Noah \& Eckstein, 1969), obsahuje následující kroky:

1. popis - zjištování dat;

2. porozumění (interpretace);

3. juxtapozice - tvorba kostry (postavení jednotlivých charakteristik porovnávaných jevů vedle sebe);

4. vlastní srovnání neboli hledání kauzalit.

Poněkud jiný postup a pořadí kroků zvolili další klasičtí badatelé srovnávací pedagogiky zabývající se problémovým přístupem v pedagogické komparatistice. Jsou jimi např. Holmes (1965) nebo empiristé Noah a Eckstein (1969). Ovšem ve všech studiích uvedených autorů hraje zásadní roli výběr a formulace problému.

\subsection{Formulace problému}

Definice objektu zkoumání a určení cíle výzkumu jsou základními stavebními kameny komparativního výzkumu, ${ }^{13}$ na které navazují další kroky. Všechny snahy o sběr dat, manipulaci s nimi, jejich třídění a následná interpretace vychází z formulace výzkumného problému a předem definovaných výzkumných předpokladů (Bereday, 1957, s. 15; 1966, s. 25; Gavora, 2010, s. 182; Manzon, 2007, s. 88). V tomto úvodním kroku je snahou badatele definovat výzkumné pole, ve kterém problém existuje. Následuje sběr informací uvnitř relativně ohraničeného výzkumného pole a precizace konceptů, které umožní co nejpřesnější definování výzkumného problému a následných výzkumných předpokladů umožňujících vědecké vysvětlení studovaného jevu (Holmes, 1965, 1981). Zásadní výhodou stanovení výzkumného problému jako východiska pro další výzkum je podle Noaha a Ecksteina (1969, s. 127) možnost výběru dat, která jsou pro daný výzkumný problém relevantní.

13 ... nejen ve srovnávací pedagogice. O důležitosti tohoto kroku hovoří také komparatisté v jiných oborech (Hroch et al., 1985; Říchová, 1997). Požadavky na formulaci výzkumného problému uvádí Mareš a Vlčková (2013, s. 467). 
Jednotlivé kroky komparace od sebe nelze striktně oddělovat, protože se vzájemně podmiňují a prolínají. Zopakujme tedy, že data je třeba shromažd'ovat přesně, $v$ dostatečném množství, nejlépe $\mathrm{z}$ různých zdrojů a především $\mathrm{v}$ relevanci k výzkumnému problému.

\subsection{Popis (deskripce)}

Popis znamená představení jasných zvláštností zkoumaných jevů, které umožňuje jednoznačné vysvětlení situace a výsledků výzkumu. Jak uvádí Váňová (1998, s. 64), cílem této fáze komparace je hloubkově a celistvě si uvědomit srovnávané jevy.

Výzkumník zde čelí problému „viditelnosti“ a „neviditelnosti“ jistých jevů, který může být přirovnán $\mathrm{k}$ ledovci. Podobně jako $\mathrm{z}$ ledovce obvykle vidíme nad hladinou jen nepatrnou část, mohou nám mnohé jevy, které vytváří základ pro viditelnou část ledovce, zůstávat skryté. To samozřejmě komplikuje porozumění danému jevu, a proto je třeba popsat jej komplexně a hloubkově. Protože $v$ komparatistice není možné činit závěry z pouhé sumy poznatků, a tedy nesystematicky, je třeba již v deskriptivní fázi postupovat podle určitých kritérií. Jelikož ne všechna kritéria jsme schopni deduktivně určit „dopředu“, můžeme použít například techniku otevřeného kódování, jak ji popisují Švaříček et al. (2007, s. 211-222). Je ale vhodné vstupovat do této fáze $s$ určitou představou o strukturaci oblastí, které budou popisovány (Bereday, 1966, s. 17). Jiné podstatné znaky se ovšem volně vynoří z datového materiálu až v průběhu deskripce (Glaser, 2004) a induktivně v dalších fázích komparace. ${ }^{14}$ Operacionalizace neboli převedení obecných pojmů do roviny sledovaných znaků (indikátorů) umožní výzkumníkovi shromažd'ovat ve vztahu k výzkumnému problému relevantní data (Noah \& Eckstein, 1969, s. 151, 166).

14 Problém polarit indukce a dedukce popisuje Seebauerová (2003). U induktivního přístupu (jako procesu vyvozování obecného závěru na základě poznatků o jednotlivostech) vycházíme z „pořadí známosti“, na jehož základě dochází k uspořádání srovnávaných objektů, a ke stanovení tertia comparationis, a to jako konstanty pro vytváření vlastních proměnných konkrétních srovnávaných objektů vytvořené z předcházejících analýz. Naproti tomu při deduktivním př́stupu (při němž od obecných závěrů, tvrzení a soudů přecházíme k méně známým a vycházíme $\mathrm{z}$ ověřených a obecně platných závěrů) je tertium comparationis (získané často z jiného srovnávacího výzkumu) rozpracováno ve formě systému kategorií a poté konkretizováno ve srovnávaných objektech (Brandl-Bradenbeck, 2005, s. 29; Noah \& Eckstein, 1969, s. 108). 
V komparatistice existují dva odlišné přístupy k získávání a především zpracovávání dat (Lauterbach \& Mitter, 1998, s. 247-248; Seebauer, 2003, s. 114-115). Prvním z př́ístupů je př́ípadově orientovaný (kvalitativní) výzkum - case-oriented research (Hendl, 2005; Švaříček et al., 2007), druhým přístupem je analyticko-empirický (kvantitativní) výzkum - variable-oriented research (Hendl, 2004). Výběr jednoho či druhého metodologického přístupu závisí na počtu zkoumaných objektů, jinak řečeno, závisí na velikosti $n,{ }_{1}^{15}$ ale především na účelu výzkumu (Bray, Adamson, \& Mason, 2007; Bray, 1990, cit. podle Thomase, 1990, s. 253-277; Rosselló, 1963, cit. podle Váňové, 1998; Walterová, 2006, s. 96). V této souvislosti jde opět především o formulaci výzkumného problému. Důležitost formulace výzkumného problému autoři (Bereday, 1957; Holmes, 1965; Noah \& Eckstein, 1969 aj.) opírají o tvrzení, že pokud tak výzkumník neučiní, není schopen rozhodnout, která data je třeba sbírat, z jakých úrovní (makro, mezo, mikro úrovně) a jaké množství dat je potřebné.

Walterová (2006, s. 98; Bereday, 1966, s. 12) uvádí, že data mohou být zjištována př́mým pozorováním $\mathrm{v}$ terénu nebo pomocí studia dokumentace (legislativních zákonů, kurikulárních dokumentů atd.). Ve srovnávacím výzkumu jsou pro zjištování primárních zdrojů informací používány především čtyři metody: pozorování, rozhovor, dotazník a nejčastěji obsahová analýza. ${ }^{16}$ Podle Noaha a Ecksteina $(1969$, s. 126, 151) komparatista může využívat také sekundární prameny, pokud jsou v relevanci k výzkumnému problému. $\mathrm{V}$ analyticko-empirických výzkumech jsou to např́íklad výsledky výzkumných studií ${ }^{17}$ TALIS, PISA, TIMSS, PIRLS atd. organizované pod záštitou IEA, $O E C D, U N E S C O$ apod. ${ }^{18}$ Pro výběr primárních zdrojů informací hovoří dle autorů možnost badatele sbírat data výhradně s ohledem na výzkumný problém, sekundární zdroje informací mají výhodu v ekonomičnosti výzkumu. Pro zvýšení reliability je v komparatistice účinná kombinace různých technik sběru dat, ${ }^{19}$ což vyžadují především tzv. multilevel komparativní studie (Bray \& Thomas, 1995).

15 Ovšem ani v kvalitativních analýzách se nelze vyhnout určité kvantifikaci (Noah \& Eckstein, 1969, s. 101).

16 To ovšem platí především pro výzkumy s malým množstvím porovnávaných jevů.

17 Techniky sběru dat v analyticko-empirických výzkumech využívajících statistických metod uvádí Hendl (2004), Molnár et al. (2012) aj.

18 Strukturu a funkce organizací zabývajících se vzdělávací politikou popisuje Manzonová (2011, s. 103-107).

19 Srov. datová triangulace (Denzin, 1989, cit. podle Hendla, 2005, s. 149; Švaříček et al., 2007) a zahrnutí více faktorů a většího množství relevantních případů, které zvyšují spolehlivost dané teorie (Bereday, 1964, s. 12-13; Noah \& Eckstein, 1969, s. 120). 


\subsection{Porozumění (interpretace)}

Collins (2001, cit. podle Zerzové, 2012, s. 19) jmenuje čtyři druhy faktorů ovlivňující porozumění, které aplikuje na vztah čtenáře a jím čteného historického textu pocházejícího z jiné kultury. Tyto čtyři faktory, které znesnadňují porozumění a interpretaci, plynou dle Collinse (2001) z oblasti historické (the historical gap), kulturní (the cultural gap), jazykové (the linguistic gap) a světonázorové (the worldview gap). Protože porozumění znamená rozpoznání hlavních znaků, opětovně zde vyvstává potřeba kontextového a v této fázi především hloubkového přístupu k porovnávaným jevům (Bray \& Thomas, 1995, s. 484) podmíněného korektním zpracováním posbíraných informací. Aby bylo možné výsledkům výzkumu lépe porozumět a následně je interpretovat, používají se $\mathrm{v}$ této fázi ${ }^{20}$ různé interpretační př́stupy plynoucí z myšlenkových směrů formalismu, strukturalismu, fenomenologie, neopragmatismu, nové kritiky, postmodernismu a dalších (Řehulková, 2010; Zouhar, 2008). ${ }^{21}$ Za klasickou metodu interpretace je považována hermeneutika (Hendl, 2005, s. 74), ovšem existují také další interpretační přístupy (Řehulková, 2010). Základním principem hermeneutiky je hermeneutický kruh. Tak je označen postup porozumění a výkladu (interpretace) výpovědi, textu, uměleckého díla, př́ípadně události nebo dokonce celku bytí (Pokorný et al., 2005).

Hermeneutický kruh má nejméně tři stádia:

1. předporozumění, s nímž interpret k vykládanému jevu přistupuje;

2. hermeneutická zkušenost, která tomuto předporozumění neodpovídá;

3. opravený rozvrh, s nímž se lze vrátit k prvnímu kroku. ${ }^{22}$

Interpretační fáze je podle Hilkera (1962, cit. podle Váňové, 1998, s. 64) nutná především proto, že pedagogická fakta jsou většinou složitá a nejednoznačná. Aby se výzkumník vyvaroval omylů, musí je interpretovat. Ovšem tím, že do interpretačního procesu zahrnujeme stále nové informace, dochází ke stále lepšímu a hlubšímu porozumění předpokladům. Podle Hendla (2005) se proto přijímá, že hermeneutické porozumění je vždy prozatímní. Shrňme tedy, že v komparatistice hermeneutický proces probíhá prakticky neustále a ukončuje se až sepsáním výzkumné zprávy.

20 Švaříček et al. (2007) o této fázi hovoří jako o primární interpretaci.

21 Vysledovat vývoj názorů na metody interpretace je velmi obtížné, nebot' jednotlivé př́ístupy inspirovaly různé filozofy a vědce a současně vzbuzovaly protikladné postoje u badatelů jiného zaměření.

22 Blíže k hermeneutické metodě Hendl (2005). 


\subsection{Juxtapozice (tvorba kostry)}

Jak uvádí Walterová (2006, s. 98), juxtapozice ještě není vlastním srovnáním. Jedná se o postavení jednotlivých charakteristik vedle sebe. ${ }^{23}$ Podle Váňové (1998) může tento krok také spočívat ve vyjádření poměru výskytu daného jevu k určitému ohraničenému celku (to platí především pro komparace s vysokým počtem proměnných). Každopádně v této fázi již vzniknou shody, podobnosti a rozdíly. Jak ale poznamenává Walterová (2006), vnější shody nebo rozdíly nejsou podstatou poznání. V této souvislosti Bereday (1966, s. 22) připomíná, že za komparativní lze považovat pouze ten postup, který je vztahován ke konkrétnímu, předem definovanému problému. Juxtapozici nebo také kostru (Švaříček et al., 2007, s. 239) komparace lze vytvořit například na základě kódovacích technik (např. techniky tematického kódování aj.) nebo obecnější analytické strategie, např́íklad konstantního komparování (Gavora, 2010; Švaříček et al., 2007; Vlček \& Janík, 2010).

\subsection{Vlastní srovnání (implikace výsledků a hledání kauzalit)}

Podle Walterové (2006, s. 98) srovnání nastává tehdy, když srovnávané fenomény vztáhneme k nadřazenému pojmu nebo hodnotě. Jedná se o vyšší stupeň zobecnění, přičemž se u srovnávaných fenoménů vylučuje vše nepodstatné a individuální a hledá se přičinná souvislost a podmíněnost výzkumných zjištění (Holmes, 1984). V této fázi se používají obecné metody analýza, syntéza, abstrakce, zobecnění, indukce a dedukce (Liu, 2008, s. 27). Toto stádium komparace je možné také připodobnit k výzkumné fázi, kterou Švaříček et al. (2007, s. 244) nazývají sekundární interpretace. Ta je podle autorů paralelní s procesem psaní výzkumné zprávy a znamená opětovné promýšlení již analyzovaného materiálu s ohledem na to, o čem naše data vlastně vypovídají, co všechna námi vynalezená schémata a tabulky znamenají a především proč k popsaným jevům dochází. Tato fáze by měla vyústit ve stanovení určitých trendů (Beraday, 1964), analýzu toho, co může být považováno za všeobecně platné (Hilker, 1962) v rámci budování teorie (Manzon, 2011), př́ípadně návrh kroků ke zlepšení situace v daném pedagogickém problému (Noah \& Eckstein, 1969).

23 Jak může vypadat kostra, neboli postavení porovnávaných jevů vedle sebe uvádí Vlček a Janík (2010, s. 67). 


\section{Závěr}

Cílem této studie bylo provést čtenáře procesem komparace $\mathrm{v}$ pedagogice (ačkoli výběrově a neúplně) vycházejícím z problémového přístupu. Pokusili jsme se navrhnout některé principy pedagogické komparatistiky a uvedli jsme možný postup a stručný popis jednotlivých kroků komparativní vědecké metody. Jak jsme již v úvodních odstavcích uvedli, metodologické požadavky na komparativní studie nejsou dostatečně specifikované, ba ani diskutované. Pokusme se proto na závěr o stručnou diskusi nikoli komplexní problematiky metodologie srovnávací pedagogiky, ale pouze vybraných témat, která jsou dle našeho názoru z hlediska kvality metodologie srovnávacího výzkumu v pedagogice podstatná.

Upřeme nejprve pozornost na roli deskriptivních studií ve výzkumném spektru srovnávací pedagogiky. Pokud jsme uvedli, že proces komparace se podle Beredaye (1966) skládá ze čtyř kroků, potom studie, která bude obsahovat popis určitého jevu (například v několika státech), není podle našeho výkladu ukončenou komparací. To ovšem neznamená, že je taková studie bezcenná. Texty tohoto druhu samozřejmě existují a mohou být velice hodnotné pro další komparativní výzkum, pakliže poskytují cenné podněty a impulsy směřující ke kladení vědeckých otázek a řešení problémů (např. Pühse \& Gerber, 2005). Podstata našeho sdělení tkví v tom, že deskripce některých pedagogických jevů, například v jiných státních celcích (state by state studies), není z metodologického hlediska komparací, ale studiem zahraniční pedagogické problematiky. Zde se shodujeme s Beredayem (1966, s. 13, 17-18, 23), Noahem a Ecksteinem (1969, s. 188), Manzonovou (2007, s. 88) aj., že studium odlišných pedagogických jevů je sice zásadní pro komparativní výzkum, ale je to pouze předpoklad celého procesu komparativního výzkumu, který začíná formulací výzkumného problému.

Jiným př́́kladem může být studie určitého pedagogického jevu, například v jiném (jen jednom) státu (single-state study). Zde je možné argumentovat tak, že výzkum komparaci v podstatě mlčky implikuje, protože autor z jedné země při výzkumu země cizí vychází z myšlení, které je vlastní jeho kultuře, čímž vnáší do výzkumu komparativní prvek. $V$ takovém případě ovšem není komparace použita ve smyslu vědecké metody, ale pouze jako obecný poznávací prostředek. Ten sice může mimo jiné obohatit poznání v pedagogické komparatistice (Bereday, 1966, s. 19; Noah \& Eckstein, 1969, s. 119), badatelé však snadno podléhají kulturní předpojatosti, nebot' v tomto př́ipadě dominuje relativistické (emické) paradigma (Noah \& Eckstein, 1969, 
s. 30, 88, 116). V podstatě se v tomto případě jedná opět o studium zahraniční pedagogické problematiky, tentokrát pouze v jednom státu. Pokud ovšem autor postupuje např́klad podle námi uvedeného postupu, tedy zejména jasně formuluje výzkumný problém dopředu, potom je taková práce, jejímž výstupem je deskripce záměrně vybraných jevů, korektním vědeckým postupem $^{24}$ a logickou mezifází s výhledem na budoucí komparaci.

Závěrem uved'me, že metodika, kterou jsme v předloženém textu nastínili, je podmíněna tím, kdo daný výzkum provádí. Role badatele je v komparatistice zcela zásadní a požadavky na výzkumníka (jeho široký kulturní rozhled, patřičná jazyková vybavenost, mezioborový teoretický a metodologický aparát) jsou nemalé (Bray \& Thomas, 1995; Keeves \& Sellin, 1988; Noah \& Eckstein, 1969). Připomeňme tedy na závěr úlohu týmové spolupráce, ${ }^{25}$ díky níž se potenciál výzkumu v moderní pedagogické komparatistice významně zvyšuje. To ovšem platí pouze za předpokladu, že jsou badatelé schopni zodpovědět esenciální otázku, tedy proč daný výzkum provádí a čeho hodlají docílit.

\section{Literatura}

Bereday, G. Z. (1957). Some discussion of methods in comparative education. Comparative Education Review, 1(1), 13-15.

Bereday, G. Z. (1966). Comparative method in education. New York: Holt, Rinehart and Winston.

Boehne, K., \& Merkens, H. (1994). Methodologische Probleme des Ost-West-Vergleichs am Beispiel der Wertforschung zu Kollektivismus. Zeitschrift für Sozialisationsforschung und Erziehungssoziologie, 14(3), 212-226.

Brandl-Bredenbeck, H. P. (2005). Comparative physical education - Why, what and how? In U. Pühse \& M. Gerber (Eds.), International comparation of physical education (s. 19-31). New York: Mayer \& Mayer.

Bray, M. (1990). The economics in education - What key economics issues concern educational planners? In R. M. Thomas (Ed.), International comparative education: Practices, issues, and prospects (s. 253-277). Oxford: Pergamon Press.

Bray, M., \& Thomas, M. (1995). Levels of comparison in educational studies: Different insights from different literatures and the value of multilevel analyses. Harvard Educational Review, 65(3), 472-490.

Bray, M., Adamson, B., \& Mason, M. (2007). Comparative education research: Approaches and methods. Hong Kong: Comparative education research centre, The University of Hong Kong.

Collins, G. R. (2001). The biblical basis of Christian counseling for people helpers. Colorado Springs: NavPress.

24 I když z logiky věci plyne, že není dodržen princip plurality.

25 Nezbytnost týmové spolupráce $\mathrm{v}$ souvislosti s tzv. multilevel komparativními studiemi zdůrazňují také Bray a Thomas (1995, s. 486), Noah a Eckstein (1969, s. 120) aj. 
Corbineau-Hoffmann, A. (2004). Einführung in die Komparatistik. Erich Schmidt: Berlin.

Cowen, R. (2009). On history and on the creation of comparative education. In R. Cowen \& A. Kazamias (Eds.), International handbook of comparative education (s. 7-10). Dordrecht: Springer.

Elley, W. B. (Ed.). (1994). The IEA study of reading literacy: Achievement and instruction in thirtytwo school systems. Oxford: Pergamon Press.

Filip, J., Svatoň, J., \& Zimek, J. (2004). Základy státovědy. Brno: Masarykova univerzita.

Gavora, P. (2010). Úvod do pedagogického výzkumu. Brno: Paido.

Glaser, B. (2004). Remodeling grounded theory. Forum: Qualitative Social Research, 5(2).

Halls, W. D. (Ed.). (1990). Comparative education: Contemporary issues and trends. Paris: UNESCO.

Hendl, J. (2004). Přehled statistických metod: zpracování dat. Praha: Portál.

Hendl, J. (2005). Kvalitativní výzkum: základní metody a aplikace. Praha: Portál.

Hilker, F. (1962). Vergleichende Pädagogik - Eine Einführung in ihre Geschichte / Theorie und Praxis. München: May Hueber Verlag.

Hofstede, G., \& Hofstede, G. J. (2005). Cultures and organizations: Software of the mind. London: McGraw-Hill.

Holmes, B. (1965). Problems in education. A comparative approach. London: Routledge and Kegan Paul.

Holmes, B. (1981). Comparative education: Some consideration of method. London: Unwin Hyman.

Holmes, B. (1984). Paradigm shifts in comparative education. Comparative Education Review, 28(4), 584-604.

Hroch, M., Bajcurová, T., Bartoš, J., Čapek, V., Jindra, Z., Kašpar, J., ... Petráň, J. (1985). Úvod do studia dějepisu. Praha: SPN.

Jellinek, G. (1882). Die Lehre von den Staatenverbindungen. Berlin: Haering.

Jireček, M. (2010). Vývoj výuky dějepisu na školách odpovídajících dnešní základní škole od roku 1918 do současnosti z hlediska vývoje kurikulárních dokumentů. In T. Janík, P. Knecht, \& P. Najvar (Eds.), Nástroje pro monitoring a evaluaci kvality výuky a kurikula (s. 111-124). Brno: Paido.

Jůva, V. (1994). Historicko-srovnávací metoda. In J. Maňák (Ed.), Kapitoly z metodologie pedagogiky (s. 66-71). Brno: Masarykova univerzita.

Keeves, J., \& Sellin, N. (1988). Multilevel analysis. In J. Keeves (Ed.), Educational research, methodology and measurement: An international handbook (s. 689-700). Oxford: Pergamon Press.

Knapp, K. (1991). Základy srovnávací právní vědy. Aleko: Praha.

Kuhn, T. (1962). The structure of scientific revolutions. Chicago: University of Chicago Press.

Lauterbach, U., \& Mitter, W. (1998). Theory and methodology of international comparisons. In Vocational education and training - the European research field background report 1998 II (s. 235-271). Thessaloniki: CEDEFOP.

Liu, B. (2008).Zeitgenössische deutsche und chinesische Sportpädagogik im Vergleich: Ausgewählte Beispiele Von der Deutschen Sporthochschule Köln zur Erlangung des akademischen Grades (Disertační práce). Köln: Institut für Pädagogik und Philosophie der Deutschen Sporthochschule. Dostupné z http://esport.dshs-koeln.de/75/1/Dissertation_Bo_Liu.pdf 
Mahoney J., \& Rueschemeyer, D. (2003). Comparative historical analysis in the social sciences. Cambridge: Cambridge University Press.

Manzon, M. (2007). Comparing places. In M. Bray, B. Adamson, \& M. Mason (Eds.), Comparative education research: Approaches and methods (s. 85-123). Hong Kong: Comparative education research centre, The University of Hong Kong.

Manzon, M. (2010). Shape-shifting of comparative education. In M. A. Larsen (Ed.), New thinking in comparative education: Honouring Rober Cowen (s. 83-101). Sense Publishers.

Manzon, M. (2011). Comparative education: The construction of a field. Hongkong: Springer.

Mareš, J., \& Vlčková, K. (2013). K metodologickým standardům kvantitativních studií v pedagogice: Jak psát o výzkumných zjištěních? Pedagogická orientace, 23(4), 455-477.

Michael, W. M., Leung, K., Ames, D., \& Lickel, B. (1999). Views from inside and outside: Integrating emic and etic insights about culture and justice judgment. The Academy of Management Review, 24(4), 781-796.

Molnár, Z., Mildeová, S., Řezanková, H., Brixí, R., \& Kalina, J. (2012). Pokročilé metody vědecké práce. Praha: Profess Consulting.

Noah, H., \& Eckstein, M. (1969). Towards a science of comparative education. London: Macmillan.

Ochrana, F. (2009). Metodologie vědy (úvod do problému). Praha: Karolinum.

Papanastasiou, C., \& Froese, V. (2002). Reading literacy in 14 countries. Lefkosia: University of Cyprus.

Píšová, M., Kostková, K., Janík, T., Doulík, P., Hajdušková, L., Knecht, P., ... Vlček, P. (2011). Kurikulární reforma na gymnáziích: př́padové studie tvorby kurikula. Praha: VÚP.

Pokorný, P., Čapek, J., Dostálová, R., Karfíková, L., Kliková, A., Mathauser, Z., ... Šmahelová, H. (2005). Hermeneutika jako teorie porozumění. Vyšehrad: Praha.

Průcha, J., Walterová, E., \& Mareš, J. (2003). Pedagogický slovník. Praha: Portál.

Průcha, J. (2006). Srovnávací pedagogika - Mezinárodní komparace vzdělávacích systémů. Praha: Portál.

Průcha, J., Walterová, E., \& Mareš, J. (2009). Pedagogický slovník. Praha: Portál.

Pühse, U., \& Gerber, M. (Eds.). (2005). International comparation of physical education. New York: Mayer \& Mayer.

Řehulková, H. (2010). K teoriím interpretace textu (Diplomová práce). Dostupné z http://is.muni. cz/th/179690/ff_m/

Richter, Ch. (2006). Konzepte für den Schulsport in Europa: Bewegung, Sport und Gesundheit. Aachen: Mayer \& Mayer.

Říchová, B. (1997). Komparativní metoda v politologii. Politologická revue, 3(2), 3-34.

Seebauer, R. (2003). Základní úvahy o plánování, realizaci a vyhodnocování vědeckých výzkumů prováděných v rámci diplomových prací a disertací. Brno: Paido.

Skalková, J. (1979). Jednota teorie a empirie. Pedagogika, 29(5), 467-478.

Skalková, J. (1995). Úvod do metodologie a metod pedagogického výzkumu. Praha: SPN.

Štefanovič, M. (1996). Základy porovnávacej právovědy. Bratislava: Vydavatelské oddelenie Právnickej fakulty Univerzity Komenského.

Švaříček, R., Šed'ová, K., Janík, T., Kaščák, O., Miková, M., Nedbálková, K. ... Zounek, J. (2007). Kvalitativní výzkum v pedagogických vědách. Praha: Portál.

Thomas, R. M. (Ed.). (1990). International comparative education: Practices, issues, and prospects. Oxford: Pergamon Press. 
Váňová, M. (1998). Teoretické a metodologické otázky srovnávací pedagogiky. Praha: Pedagogická fakulta Univerzity Karlovy.

Vlček, P., \& Janík, T. (2010). Školské reformy a tvorba kurikula tělesné výchovy v České republice, Spolkové republice Německo a Spojených státech amerických. Brno: Paido.

Walterová, E. (2006). Srovnávací pedagogika: Vývoj a proměny v globálním kontextu. Univerzita Karlova v Praze: Pedagogická fakulta.

Walterová, E. (2014). Problémy srovnávací pedagogiky jako předmětu vysokoškolské výuky ve světě a v českém prostředí. Pedagogická orientace, 24(5), 663-698.

Zerzová, J. (2012). Interkulturní komunikační kompetence a její rozvíjení v hodinách anglického jazyka. Brno: Masarykova univerzita.

Zouhar, J. (2008). Dějiny českého filozofického myšlení do roku 1968. Brno: Academicus.

\title{
Autor
}

PhDr. Mgr. Petr Vlček, Ph.D., Masarykova univerzita, Pedagogická fakulta, Katedra tělesné výchovy, Poříćí 31, 60300 Brno, e-mail: vlcek@ped.muni.cz

\section{Comparative education research: Some considerations about the problem approach methodology}

\begin{abstract}
The paper deals with selected problems concerning the methodology of comparative education research. The goal of the paper is to contribute to the discussion about the methodological quality of comparative research in education. The author tries to lead the reader through the comparative education research process based on the problem approach. Apart from the brief theoretical and historical foundations of the study the author presents the basic principles of comparative research derived from the current approach to comparative education and its field of study and selected types of comparative education research. Subsequently, particular steps of the comparative research method are named. The final part deals with the role and place of single case study and state by state study in comparative education studies from the problem oriented methodology point of view.
\end{abstract}

Keywords: comparative education, methodology, problem approach 